Spring 1997

\title{
A Feminist View of American Elder Law
}

Rebecca Korzec

University of Baltimore School of Law, rkorzec@ubalt.edu

Follow this and additional works at: http://scholarworks.law.ubalt.edu/all_fac

Part of the Elder Law Commons, Family Law Commons, and the Law and Gender Commons

\section{Recommended Citation}

A Feminist View of American Elder Law, 28 U. Tol. L. Rev. 547 (1997)

This Article is brought to you for free and open access by the Faculty Scholarship at ScholarWorks@University of Baltimore School of Law. It has been accepted for inclusion in All Faculty Scholarship by an authorized administrator of ScholarWorks@University of Baltimore School of Law. For more information, please contact snolan@ubalt.edu. 


\title{
A FEMINIST VIEW OF AMERICAN ELDER LAW
}

\author{
Rebecca Korzec
}

\section{INTRODUCTION}

$\Lambda \mathrm{NY}$ discussion of contemporary American elder law must consider gender

$\mathrm{A}_{\text {issues. }}{ }^{\prime}$ A number of gender concerns are readily discernible, including workplace and family issues. Significantly, sex-based disparities are increasing within the elderly population. ${ }^{2}$ In turn, these disparities exacerbate problems of fairness and equity in meeting intergenerational family needs and expectations. ${ }^{3}$

As with childrearing, in contemporary American society, the major caregiving responsibility for the growing number of frail elderly falls largely on women rather than men. ${ }^{4}$ With an increasing number of women working outside the family home, ${ }^{5}$ the intersection of work and family issues is receiving considerable attention both in academic circles ${ }^{6}$ and in the popular media.' Recently, for example, twenty-

- Professor of Law, University of Baltimore School of Law.

1. See, e.g., Sarah H. Matthews, Gender Roles and Filial Responsibility, in GENDER ROLES THROUGH THE LifE SPAN: A MUlTi-DisciplinaRY PERSPECTIVe 245, 245-54 (Michael R. Stevenson ed., 1994) [hereinafter GENDER RoLES]. "Research on relationships between elderly parents and their adult children conducted in the past twenty-five years seems to support the old adage, 'if you have a daughter you have a daughter for life; if you have a son you lose him to a wife." Id. at 245 . A general introduction to the legal issues of the elderly is provided by LAURENCE A. FroLIK \& RICHARD L. KAPLAN, ELDER LAW IN A NUTSHELl (1995).

2. See, e.g., Toni C. Antonucci et al., Sex Differences in Age and Racial Influences in Productive Activities, in GeNDER Roles, supra note 1, at 259, 268-71; Diane M. Pearce \& Kelley Ellsworth, Welfare and Women's Poverty: Reform or Reinforcement?, $16 \mathrm{~J}$. LEGIS. 141, 141-50 (1990). The gender disparity in wages for older women is greater than for younger women. In 1983, women in the $55-59$ age range earned only $57 \%$ of the amount earned by men; between $20-24$, women earned $86.3 \%$ of men's earnings. Katharine T. Bartlett, Gender and Law: Theory, Doctrine, Commentary 284 (1993) (citing Francine D. Blau \& MARIANNe A. Ferber, The ECONOMICS OF WOMEN, MEN, AND WORK 177 (1986)).

3. See Nancy E. Dowd, Family Values and Valuing Families: A Blueprint for Family Leave, 30 HARV. J. ON LEgIS. 335, 342 (1993). See generally Martin H. Malin, Fathers and Parental Leave, 72 TEX. L. REV. 1047, 1049-64 (1994).

4. See, e.g., ARLie Hochschild, The Second Shift: Working Parents and the Revolution AT HOME 276 (1989); Judith T. Younger, Light Thoughts and Night Thoughts on the American Family, 76 MINN. L. REV. 891, 898-99 (1992).

5. The number of women workers almost doubled between 1960 and 1980. By 1993, women comprised $45.6 \%$ of the workforce, about 58.4 million women. BUREAU OF THE CENSUS, U.S. DEP'T of COMmerce, Statistical Abstract OF THE UNited States: 1994, at 396 (114th ed. 1994).

6. See generally LUCY FISHER, LINKED LIVES: ADULT MOTHERS AND THEIR DaUGHTERS (1986); Helen ZNANIECKa Lopata \& HeNRy BREHM, Widows and DePENDENT Wives 1542 (1986); Kathryn Abrams, "Gender Discrimination" and the Transformation of Workplace Norms, 42 VAND. L. REV. 1183 (1989).

7. See generally Elizabeth Perle McKenNa, When Work Doesn't WORK ANymore: WOMEN, WorK, AND IDENTITY (1997); JOAN K. PETERS, WHEN MOTHERS WORK: LOVING OUR 
nine colleges and universities were identified as having workplace policies sensitive to employee family care responsibilities. ${ }^{8}$ Regrettably, such workplaces are the exceptions in American society.'

This article examines these significant elder law issues from a feminist perspective, ${ }^{10}$ particularly the feminist jurisprudence of care. ${ }^{11}$ Feminism has much to teach traditional American law and jurisprudence, ${ }^{12}$ including elder law. Feminist jurisprudential approaches have provided valuable critiques of traditional legal topics, including tort law, ${ }^{13}$ family law, ${ }^{14}$ corporate law, ${ }^{15}$ tax law, ${ }^{16}$ commercial law, ${ }^{17}$ labor law, ${ }^{18}$ and international law. ${ }^{19}$ This article applies similar feminist sensibilities ${ }^{20}$ and methodologies ${ }^{21}$ to elder law concerns.

Children Without Sacrificing Our Selves (1997); Dan Cordtz, Hire Me, Hire My Family, Fin. WORLD, Sept. 18, 1990, at 76.

8. Robin Wilson, A Report Praises 29 Colleges for 'Family Friendly' Policies: But other institutions are faulted for failing to help employees with child care and aid for sick relatives, CHRON. HIGHER EDUC., Oct. 11, 1996, at A13-15. Among the colleges and universities listed were: Cornell, Harvard, Johns Hopkins, Stanford, University of California System, and the University of Chicago.

9. See, e.g., Donna L. Wagner, Eldercare: A Workplace Issue, in GROWING OLD IN AMERICA (Beth B. Hess \& Elizabeth W. Markson eds., 1992). See also Abrams, supra note 6, at 1243; Nancy Dowd, Work and Family: The Gender Paradox and the Limitations of Discrimination Analysis in Restructuring the Workplace, 24 HARV. C.R.-C.L. L. REV. 79, 86 (1989).

10. See, e.g., Katherine T. Bartlett, Feminist Legal Methods, 103 HARV. L. REV. 829, 836-49 (1990).

11. See, e.g., Leslie Bender, From Gender Difference to Feminist Solidarity: Using Carol Gilligan and an Ethic of Care in Law, 15 VT. L. REv. 1, 19-20 (1990).

12. See generally DRUCILla CORNELL, BEYOND ACCOMMODATION: ETHCAL FEMINISM, DECONSTRUCTION AND THE LAW (1991); SUSAN ESTRICH, REAL RAPE (1987); JOAN HOFF, LAW, GENDER, AND INJUSTICE (1991); BELL HOOKS, YEARNING: RACE, GENDER, AND CULTURAL POLITICS (1990); CATHERINE A. MACKINNON, TOWARD A FEMINIST THEORY OF THE STATE (1989).

13. Leslie Bender, $A$ Lawyer's Primer on Feminist Theory and Tort, 38 J. LEGAL Educ. 3, 20 (1988).

14. Martha Albertson Fineman, Societal Factors Affecting the Creation of Legal Rules for Distribution of Property at Divorce, in AT THE BOUNDARIES OF LAW: FEMINISM AND LEGAL THEORY 265-78 (Martha Albertson Fineman \& Nancy Sweet Thomadsen eds., 1991).

15. Kathleen A. Lahey \& Sarah W. Salter, Corporate Law in Legal Theory and Legal Scholarship: From Classicism to Feminism, 23 OsGOODE HaLL L.J. 543, $544-57$ (1985).

16. Marjorie E. Kornhauser, The Rhetoric of the Anti-Progressive Income Tax Movement: A Typical Male Reaction, 86 MICH. L. REV. 465, 506-11 (1987).

17. Karen Gross, Re-Vision of the Bankruptcy System: New Images of Individual Debtors, 88 MICH. L. REV. 1506, 1532 (1990).

18. Marion Crain, Images of Power in Labor Law: A Feminist Deconstruction, 33 B.C. L. REV. 481, 511 (1992); Marion Crain, Feminizing Unions: Challenging the Gendered Structure of Wage Labor, 89 MiCH. L. REV. 1155, 1184-86 (1991).

19. Hilary Charlesworth et al., Feminist Approaches to International Law, 85 AM. J. INT'L L. 613, 634 (1991); Karen Engle, International Human Rights and Feminism: When Discourses Meet, 13 MiCH. J. INT'L L. 517, 531-35 (1992).

20. See, e.g., Robin L. West, Jurisprudence and Gender, 55 U. CHI. L. REV. 1, 4-5 (1988); Joan C. Williams, Deconstructing Gender, 87 MICH. L. REV. 797, 798 (1989). Deborah Rhode has suggested that feminist theories have three things in common:

On a political level, they seek to promote equality between women and men. On a substantive level, feminist critical frameworks make gender the focus of analysis; their aim is to reconstitute legal practices that have excluded, devalued, or undermined women's concerns. On a 
In general, American elder law is traditional in approach. Traditional or classical American jurisprudence, like elder law, promotes autonomy, personal responsibility, rationality, and individualism..$^{22}$ On the other hand, feminism, especially the feminist "ethic of care" associated with the work of Carol Gilligan, ${ }^{23}$ rejects these traditional concepts in favor of solidarity, empathy, and community responsibility. ${ }^{24}$ This article argues that the feminist ethic of care should displace the traditional American approach to elder law.

\section{THE FEMINIST ETHIC OF CARE}

Women's "different voice"2s theory views the ethic of care as a superior model of legal reasoning and societal organization. ${ }^{26}$ For example, the feminist ethic of

methodological level, these frameworks aspire to describe the world in ways that correspond to women's experiences and that identify the fundamental social transformations necessary for full equality between the sexes.

Deborah L. Rhode, Feminist Critical Theories, 42 STAN. L. REV. 617, 619 (1990).

21. See, e.g., Bartlett, supra note 10, at 836-49; Christine A. Littleton, Reconstructing Sexual Equality, 75 CAL. L. REV. 1279, 1293-1301 (1987); Martha Minow, Feminist Reason: Getting It and Losing $l t, 38$ J. LEGAL EDUC. 47, 48-49 (1988).

22. By this I mean that individuals are viewed as primarily responsible for their own needs as they age; society and government need only provide a "safety net" against individual calamity. See, e.g., Leslie A. Morgan, Economic Security of Older Women: Issues and Trends for the Future, in GROWING OLD IN AMERICA, supra note 9, at 275. Linda C. McClain explains that the term "autonomy" may have two distinct meanings-one associated with isolation; the other, with selfgovernance.

The prominence of moral development and psychological theory in feminist jurisprudence might explain part of the confusion of the meanings of autonomy. The mixture of those distinct but overlapping meanings has obscured the extent to which feminists and liberals share kindred concerns. Autonomy need not be atomistic, and ... autonomy as self-government [may coexist] with and include many forms of connection among citizens.

Linda C. McClain, 'Atomistic Man' Revisited: Liberalism, Connection, and Feminist Jurisprudence, 65 S. CAL. L. REV. 1171, 1190 (1992).

23. Carol Gllligan, in a Different Voice: Psychological Theory and Women's DEVELOPMENT 62-63 (1982).

24. See, e.g., Minow, supra note 21 , at $47-48$ ("Feminists have shown how . . assertions of neutrality hide from view the use of a male norm. ... Adopting such feminist critiques can deepen the meaning of equality under law. I advocate developing similar feminist critiques in contexts beyond gender, such as religion, ethnicity, race, handicap, sexual preference, socioeconomic class, and age.").

25. See, e.g., Leslie Bender, Feminist (Re)Torts: Thoughts on the Liability Crisis, Mass Torts, Power, and Responsibilities, 1990 DUKE L.J. 848, 901 -02 (1990); Lucinda M. Finley, Transcending Equality Theory: $A$ Way Out of the Maternity and Workplace Debate, 86 COLUM. L. REV. 1118, 1129 n.56 (1986); McClain, supra note 22, at 1188-94; Margaret Jane Radin, The Pragmatist and the Feminist, 63 S. CAL. L. REV. 1699, 1712 (1990).

26. GILligan, supra note 23, at 166,174. See also Carrie Menkel-Meadow, Mainstreaming Feminist Legal Theory, 23 PAC. L.J. 1493, 1497-1522 (1992). But see Richard A. Posner, Conservative Feminism, 1989 U. CHI. LEGAL F. 191, 214 (arguing that "Gilligan's ethic of care cannot be made the basis for a coherent feminist jurisprudence"). Gilligan's "different voice" theory has its critics. See generally Carol TA VRIS, THE MiSMEASURE OF WOMAN 79-90 (1992); John Broughton, Women's Rationality and Men's Virtues: A Critique of Gender Dualism in Gilligan's Theory of Moral 
care values interconnectedness and relationships ${ }^{27}$ over the traditional "male" characteristics of individualism and rights. ${ }^{28}$

Carol Gilligan identified two distinct approaches to moral problem-solving. The first resembles the dominant rationality and methodology of traditional American jurisprudence. This traditional model is rights-based, emphasizing the use of generalized principles and rules to settle disputes between individuals. Under this approach, the justice-oriented, "neutral" problem-solver/decision-maker embodies a heightened moral development. Historically, this traditional approach monopolized American jurisprudence. ${ }^{29}$

Gilligan's second approach comprises an ethic of care, focusing on the unique factual context as well as on the parties' interdependencies and interpersonal responsibilities and rights. ${ }^{30}$ This ethic of care rejects adversarial disputes in favor of preserving on-going relationships and forging cooperative solutions grounded in the specific facts of the problem at hand. ${ }^{31}$ Significantly, Gilligan argues that although both men and women employ care concerns, women employ them more often and more consistently because they tend to focus more energy and time on personal relationships. ${ }^{32}$ She concludes that for men "the moral imperative appears rather as an injunction to respect the rights of others and thus to protect from interference the rights to life and self-fulfillment." ${ }^{" 33}$

Development, 50 SOC. RES. 597, 603 (1983); Catherine G. Greeno \& Eleanor E. Macoby, How Different is the Different Voice?, 11 SIGNS 310, 316 (1984).

27. GILlIGAN, supra note 23 , at 160.

28. Id. at 100 .

29. See generally CATHARINE MACKINNON, TOWARD A FEMINIST THEORY OF THE STATE 237 (1989); Ann C. Scales, The Emergence of Feminist Jurisprudence: An Essay, 95 YALE L.J. 1373, 1380 (1986). Robin West argues that "[t]he values that flow from women's material potential for physical connection are not recognized as values by the Rule of Law, and the dangers attendant are not recognized as dangers by the Rule of Law." West, supra note 20, at 58 . Leslie Bender notes that Gilligan identified two distinct methods of moral problem solving.

One perspective, which [Gilligan] denominated an ethic of justice, closely parallels the dominant rationality and methodology of Anglo-American law. The justice ethic is based on a rights model, where problem-solving consists of the application of abstract, generalized principles to arbitrate rights disputes between separate individuals.

Bender, supra note 11, at 36-37.

30. GILligAN, supra note 23, at 100-104.

31. Id. See also Bender, supra note 25, at 905-07; Finley, supra note 25, at 1172.

32. GILLIGAN, supra note 23, at 62-63. See generally Littleton, supra note 21, at 1293-1301.

For a compelling critique of Gilligan's ethic of care, see McClain, supra note 22, at 1196-1202.

33. GILLIGAN, supra note 23 , at 62-63. Gilligan's work forms the basis of cultural feminism, which Robin West describes as follows:

Cultural feminism does not simply identify women's differences-patriarchy too insists on women's differences-it celebrates them. ... Women's ways of knowing, and women's heart, are all, for the cultural feminist, redefined as things to celebrate. ... Integrative knowledge is not a confused and failed attempt to come to grips with the elementary rules of deductive logic; it is a way of knowledge and should be recognized as such. ... Women's distinctive aesthetic sense is as valid as men's. Most vital, however, for cultural feminism is the claim that intimacy is not just something women do, it is something human beings ought to do. Intimacy is a source of value, not a private hobby. It is morality, not a habit. 
Clearly, the epistemological argument that women know things differently from men is controversial. ${ }^{34}$ Feminists continue to debate whether women's focus on care and relationships is inherently female ${ }^{35}$ (the essentialist view) or the result of life experiences, such as mothering or facing discrimination. ${ }^{36}$

Although scholars have focused on Gilligan's theme that women speak in a "different voice," a voice possessing "more advanced, more affiliative ways of living, ${ }^{37}$ Gilligan's work advances an equally compelling second message. She argues that traditional, stereotypical notions of masculinity and femininity warp true human potential for leading a balanced, authentic life; the masculine stereotype neglects care of others, while the feminine stereotype neglects care of self. ${ }^{38}$

Employing either explicit or implicit male-based norms when analyzing elder law issues creates disadvantages for women. However, change must be more than semantic. Changing mere words without changing their underlying assumptions about men and women is largely meaningless. Here, a significant analogy in tort analysis may enhance our understanding. At one time, the negligence law's standard of care focused on the "reasonable man" or "man of reasonable prudence. ${ }^{" 39}$ To avoid the overt sexism of this standard, negligence jurisprudence

West, supra note 20 , at 28 (emphasis added).

34. See, e.g., Carrie Menkel-Meadow, Culture Clash in the Quality of Life in the Law: Changes in the Economics, Diversification and Organization of Lawyering, 44 CASE W. RES. L. REV. 621, 64344 \& n. 110 (citing MAY F. BELENKY ET AL., WOMEN'S WAYS OF KNOWING: THE DEVELOPMENT OF SELF, VoICE, AND MIND (1986)). See also Posner, supra note 26, at 193-214.

35. See, e.g., West, supra note 20, at 26-27. See generally NANCY CHODOROW, REPRODUCTION OF MOTHERING: PSYCHOANAL YSIS AND THE SOCIOLOGY OF GENDER 7 (1986) ("[W]omen, as mothers, produce daughters with mothering capacities and the desire to mother.").

36. See, e.g., Williams, supra note 20 , at 803, n. 17 .

37. GILligAN, supra note 23 , at 49 .

38. Id. at 168-74. This is evidenced, for example, by the fact that women generally devote not only physical energy and attention to the needs of others, but also mental energy and attention. See generally Rebecca Korzec, Working on the "Mommy-Track": Motherhood and Women Lawyers, 8 HASTINGS WOMEN'S L.J. 117 (1997).

39. See, e.g., Osborne M. Reynolds Jr., The Reasonable Man of Negligence Law: A Health Report on the "Odious Creature," 23 OKLA. L. REV. 410, 410, 414 (1970). See also A.P. HERBERT, UNCOMMON LAW 1, 5-6 (8th ed. 1969) (for an amusing satire demonstrating the sexism of the standard). Herbert's hypothetical judge declares that:

[M]y own researches incline me to agree, that in all that mass of authorities which bears upon this branch of the law there is no single mention of a reasonable woman. It was ably insisted before us that such an omission, extending over a century and more of judicial pronouncements, must be something more than a coincidence; that among the innumerable tributes to the reasonable man there might be expected at least some passing reference to a reasonable person of the opposite sex; that no such reference is found, for the simple reason that no such being is contemplated by law; that legally at least there is no reasonable woman, and that therefore in this case the learned judge should have directed the jury that, while there was evidence on which they might find that the defendant had not come up to the standard required of a reasonable man, her conduct was only what was to be expected of a woman, as such ....

... It is probably no mere chance that in our legal text-books the problems relating to married women are usually considered immediately after the pages devoted to idiots and lunatics. Indeed, there is respectable authority for saying that at Common Law this was the status of a 
began employing a "reasonable person" standard ${ }^{40}$ However, this apparently sweeping semantic alternative itself proved problematic. As Leslie Bender explains:

This "resolution" of the standard's sexism ignores several important feminist insights. The original phrase "reasonable man" failed in its claim to represent an abstract, universal person. Even if such a creature could be imagined, the "reasonable man" standard was postulated by men, who, because they were the only people who wrote and argued the law, philosophy, and politics at that time, only theorized about themselves. When the standard was written into judicial opinions, treatises, and case books, it was written about and by men. ${ }^{41}$

Similarly, Guido Calabresi asks whether the term "reasonable person" includes women or people of non-WASP (non-White Anglo-Saxon Protestant) beliefs. ${ }^{42}$ Significantly, the use of this seemingly universal standard may be intended to cause those who would be "different" from the male-based norm to adopt the dominant analysis. ${ }^{43}$ As a result, the reasonable person standard may actually invalidate "different voices."

This invalidation of the feminist perspective decreases the likelihood that the quality of social, political, and legal decision-making will improve. When the system of legal analysis embraces many different perspectives-including perspectives of gender, race, and ethnicity-the quality of ideas must necessarily improve ${ }^{45}$ Contemporary elder law must reexamine basic questions, subjecting the old orthodoxies to renewed scrutiny and debate. Without revitalization and reendorsement, society's value systems might harden into a desiccated orthodoxy, which individuals perceive as merely an external imposition of restrictive, outmoded rules.

Feminist jurisprudence can vitalize this process of debate and reconsideration. As a paradigm for analysis of elder law questions, the feminist ethic of care can illuminate new insights and expose values having true worth that may have been hidden from view by the current elder law system. Analysis of areas in which gender-based distinctions have affected elder law jurisprudence leads inexorably

woman .... It is no bad thing that the law of the land should here and there conform with the known facts of everyday experience. The view that there exists a class of beings, illogical, impulsive, careless, irresponsible, extravagant, prejudiced, and vain, free for the most part from those worthy and repellent excellences which distinguish the Reasonable Man, and devoted to the irrational arts of pleasure and attraction, is one which should be as welcome and as well accepted in our Courts as it is in our drawing-rooms-and even in Parliament .... I find that at Common Law a reasonable woman does not exist.

Id.

40. See, e.g., Bender, supra note 13, at 3-5.

41. Id. at 22 .

42. GuIDo Calabresi, Ideals, Beliefs, ATtTudes, and the Law: PrJvate Law Perspectives ON A PUBLIC LAW PROBLEM 26-28 (1985).

43. Id.

44. Id. at 28.

45. Menkel-Meadow, supra note 34, at 642-43. 
to the conclusion that traditional American jurisprudence perpetuates gender discrimination. ${ }^{46}$ This examination from a feminist perspective can only broaden analysis and insight, ultimately producing a more responsive elder law jurisprudence. ${ }^{47}$

\section{GENDER ISSUES IN BALANCING WORK AND FAMILY}

\section{A. Women as Disadvantaged Workers}

The current legal ${ }^{48}$ and workplace ${ }^{49}$ systems are structured largely around male norms. Fundamentally, the traditional American workplace is based on the model of the average ideal worker: a decidedly male norm. ${ }^{50}$ This ideal worker essentially devotes all his time to career advancement; his wife subsidizes his efforts by providing homemaking and childrearing services. ${ }^{51}$ Moreover, the ideal worker-the male worker - toils full-time without interruptions for childbirth, childrearing ${ }^{52}$ or caretaking of elderly parents. ${ }^{53}$ Establishing the normal male life

46. See, e.g., Ruth Bader Ginsburg, Gender and the Constitution, 44 U. CN. L. REV. 1, 4-8 (1975) (discussing the ways American law has historically discriminated against women); John D. Johnston, Sex and Property: The Common Law Tradition. The Law School Curriculum, and Developments Toward Equality, 47 N.Y.U. L. REV. 1033, 1044-70 (1972) (discussing how property law has historically discriminated against women).

47. Id. at 642-43. Carrie Mendel-Meadow argues that:

Just as "two heads are better than one," . . two genders . . . cannot but help increase the number and quality of ideas in circulation for solving legal problems and revising conventional takenfor-granted categories. ... Any disruption of conventional and dominant group thinking must improve the quality of legal decision-making.

Id.

48. See, e.g., Barbara Reskin \& Patricia A. Roos, Job QueUes, Gender Queues: EXPLAINING WOMEN'S INROADS INTO MALE OCCUPATIONS 3-6 (1990); Williams, supra note 20, at 822. See also supra notes 41-42.

49. See, e.g., Clatr Brown \& Joseph A. Pechman, Gender In THE Work Place ExeCutives AND ORGANIZATIONS 3-11 (1987); Felice N. Schwartz, Management Women and the New Facts of Life, 67 HARV. BuS. REV. 65, 66-68 (1989).

50. See Williams, supra note 20 , at 822.

51. See HoCHSCHID, supra note 4, at 6-10 (noting employed women in the labor force still have primary responsibility for childrearing and housekeeping). See generally THE WHITE HOUSE WORKING GROUP ON THE FAMILY, THE FAMILY: PRESERVING AMERICA's FUTURE (1986). See also Williams, supra note 20 , at 805 .

52. See, e.g., Proclamation No. 172, 45 Fed. Reg. 58,325 (1980) (noting that President Jimmy Carter stated: "[w]orking mothers do not shed homemaking and parental responsibilities; they merely add the demands of a job to those of wife and mother"); Jennifer A. Kingston, Women in the Law Say Path is Limited by 'Mommy-Track,' N.Y. TMME, Aug. 8, 1988, at Al (noting that women often reduce the number of hours worked to "mommy track:" devoting substantial time to childrearing at the cost of career or professional advancement). See also Geneva Overholser, So Where's the Daddy Track?, N.Y. TIMES, Aug. 25, 1988, at A26. Other women "sequence" by leaving the workplace altogether for a period of time to devote time to family caretaking. See, e.g., Sara Rimer, Sequencers: Putting Careers on Hold, N.Y.TimES, Sept. 23, 1988, at A21.

53. See, e.g., Matthews, supra note 1, at 249-50. 
cycle as the legal and workplace norms creates disadvantages for women ${ }^{54}$ and suppresses the expression of women's concerns. ${ }^{55}$ Inequities are created for women when men are explicitly and implicitly seen as the norm, and women are viewed as a deviation from that norm. ${ }^{56}$

The results of these legal and workplace norms become evident-measured in traditional terms, ${ }^{57}$ women lag behind men in professional advancement. ${ }^{58}$ The current literature on the achievements of women lawyers is instructive. Significant numbers of women began entering the legal profession in the $1970 \mathrm{s.}{ }^{59}$ However, mere access to the profession has not resulted in equal participation for women:60 at all levels women lawyers earn less than their male counterparts. ${ }^{61}$ Moreover, women lawyers are less likely to become partners in law firms, judges, or full professors in law schools. ${ }^{62}$ The fact that women lawyers-women knowledgeable in the law - have failed to achieve parity in the traditional workplace demonstrates that gender discrimination must be systemic in the American workplace. ${ }^{63}$

54. In 1990 , women earned $71.8 \%$ of the median weekly earnings of men. BUREAU OF LABOR STATISTICS, U.S. DEP'T OF LABOR, BULlEITN NO. 2385, WORKING WOMEN: A CHARTBOOK 44 (1991) [hereinafter WorkING WOMEN]. See also Susan McGee Bailey \& Patricia B. Campbell, Gender Equality: The Unexamined Basic of School Reform, 4 STAN. L. \& PoL'Y REV. 73, 75 (1993) (noting that although women on average earn only "slightly more than two-third's of a man's salary," their wages are an important part of total family income, especially for African-American and Hispanic families). As late as $1990,59 \%$ of employed women worked in only three occupational areas: clerical, service, or sales. WORKNNG WOMEN, supra at 15 . At the same time, the statistics for men were quite different; $13.8 \%$ in executive, administrative, or managerial jobs, $12 \%$ in the professions, and $40 \%$ in production, craft, operator, fabrication, or laborer occupations. WORKING WOMEN, supra at 42.

55. See FED. GlaSS CEILING COMM'N, U.S. DEP'T OF LABOR, GOOD FOR BuSINESS: MAKING FULL USE OF THE NATION'S HUMAN CAPITAL 34 (1995) (discussing the pressure women feel in trying to conform to the norms and rules of the white male corporate climate) [hereinafter FED. GLASS CEILING COMM'N]; Cynthia Fuchs Epstein, Faulty Framework: Consequences of the Difference Model for Women in the Law, 35 N.Y.L. SCH. L. REV. 309, 317 (1990).

56. See, e.g., Susan Bordo, The Cartesian Masculinization of Thought, in SEX AND SCIENTIFIC INQUIRY 247-64 (Susan Harding \& Jean F. O'Barr eds., 1987); Jane Flax, Political Philosophy and the Patriarchal Unconscious: Psychoanalytic Perspective on Epistemology and Metaphysics, in DisCOVERING REALITY 245, 269 (Sandra Harding \& Merrill B. Hintikka eds., 1983).

57. See, e.g., FED. Glass CEILING COMM'N, supra note 55, at 34; Deborah L. Rhode, Perspectives on Professional Women, 40 STAN. L. REV. 1163, 1178-81 (1988).

58. See, e.g., A.B.A. COMM'N ON WOMEN IN THE PROFESSION, UNFINISHED BUSINESS: OVERCOMING THE SISYPHUS FACTOR 5 (1995).

59. Barbara A. Curran \& Clara N. Carson, Supplement to the lawyer Statistical REPORT: THE U.S. LEGAL PROFESSION IN 1988, at 2, 7, 14 (1991).

60. See generally A.B.A COMM'N WOMEN IN THE PROFESSION, supra note 58, at 5-17.

61. Id. at 12. Among lawyers in practice from one to three years, men earn $\$ 37,500$, while women earn $\$ 30,806$; men working as corporate general counsel earn $\$ 205,000$, while women earn $\$ 152,000$. Id. at 11 .

62. Id. at 6-17. See also Janet Taber et al., Project, Gender, Legal Education, and the Legal Profession: An Empirical Study of Stanford Law Students and Graduates, 40 STAN. L. REV. 1209, 1224 (1988); Robert J. Borthwick \& Jordan R. Schau, Gatekeepers of the Profession: An Empirical Profile of the Nation's Law Professors, 25 U. MicH. J.L. REF. 191, 199-212 (1991).

63. See generally Cynthia Fuchs Epstein et al., Glass Ceilings and Open Doors: Women's Advancement in the Legal Profession, 64 FORDHAM L. REV. 291 (1995). See also Ruth Blumrosen, Wage Discrimination, Job Segregation, and Title VII of the Civil Rights Act of 1964, 12 U. MICH. J. L. REFORM 397, 415-20, 455-57 (1979) (addressing the effects of sexual job segregation and sexual stereotyping on the wage gap between men and women); Paul Weiler, The Wages of Sex: The Uses 
Women's economic disadvantages translate to lesser lifetime earnings ${ }^{64}$ and smaller pensions. ${ }^{65}$ These economic facts help explain the growing poverty suffered by elderly women, including the frail elderly. ${ }^{66}$ Ultimately, women's work interruptions for childbirth, childrearing, and family responsibilities result from the gendered nature of family roles in American family life. ${ }^{67}$ Clearly, these gendered family roles impoverish women financially. More fundamentally, they may psychologically and socially impoverish both men and women by discouraging the creation of balanced personal and professional lives. ${ }^{68}$

\section{B. Gender Roles in the Care of Elderly Parents}

In contemporary American society, members of nuclear families are encouraged to be "not only economically independent of one another with the passage of time, but emotionally independent as well." ${ }^{.69}$ Research conducted over the past twentyfive years studying the relationships of elderly parents and their adult children indicate that the traditional assignment of gender roles occurs in carrying out filial

and Limits of Comparable Worth, 99 HARV. L. REv. 1728, 1779-84 (1986) (arguing that even the smallest estimate of the gender wage gap "implies a substantial injustice"). For discussions of the legislative history of Title VII of the Civil Rights Act of 1964 forbidding sex-based discrimination in employment, see Caroline Bird, Ladies Day in the House, in BORN FEMALE 1-15 (1969); LeO KANOWITZ, WOMEN AND THE LAW: THE UNFINISHED REVOLUTION 104-05 (1969); Developments in the Law-Employment Discrimination and Title VII of the Civil Rights Act of 1964, 84 HARV. L. REV. 1109,1167 (1971).

64. Bonnie Thomton Dill et al., Race and Gender in Occupational Segregation, in PAY EQUITY AN ISSUE OF RACE, ETHNICITY \& SEX 11, 63 (1987) (stating that over lifetime, women eam $58 \%$ of men's income).

65. Judy Mann, Pensions Short-Change Women, WASH. Post., Aug. 16, 1995, at E17. See Women's Pension Equity Act of 1996, S. 1756, 104th Cong. (1996). Two of the provisions requiring the creation of model language for a qualified joint and survivor annuity and for a quality domestic relations order were incorporated in the Small Business Jobs Protection Act of 1996, Pub. L. No. 104188, 110 Stat. 1755 (1996). Less than one-third of female private retirees have private pensions. U.S. DEP'T OF LABOR, RETIREMENT BENEFITS OF AMERICAN WORKERS 51 (1995). See also OLDER WOMEN's LEAGUE, THE PATH TO POVERTY: AN ANAL YSIS OF WOMEN'S RETIREMENT INCOME, 1995 MOTHER'S DAY REPORT, 1, 3 (1995) (indicating that the average social security benefit for a woman based on her own earnings is $\$ 538$ a month).

66. See BUREAU OF THE CENSUS, U.S. DEP'T OF COMMERCE, Poverty in the United States: 1992, in CURRENT POPULATION REPORTS, at tbl. 5 (1992) (noting that women comprise just under $60 \%$ of senior citizens over 65 , but $75 \%$ of the poor elderly).

67. See, e.g., Deborah L. Rhode, Myths of Meritocracy, 65 FORDHAM L. REV. 585, 591 (1996) ("Women's career sacrifices are attributable not just to women's choices but to men's choices as well. Male spouses' failure to shoulder equal family responsibilities and male colleagues' failure to support alternative working arrangements are also responsible."); Kerry Hannon, $A$ Woman 's Special Dilemma, U.S. NEWS \& WORLD REP., June 13, 1994, at 93 (stating that a woman with a 40 -year career who interrupts it for seven years will receive half the pension she would have received from continuous employment).

68. For example, the lawyer who works 2,000 billable hours or more does not have time to be a spouse, parent, or friend and may demonstrate distress. See, e.g., Connie J.A. Beck et al., Lawyer Distress: Alcohol Related Problems and Other Psychological Concerns Among a Sample of Practicing Lawyers, 10 J.L. \& HEALTH 1, 3 (1995-96).

69. Matthews, supra note 1 , at $245-46$. 
responsibility. ${ }^{70}$ As a result, adult sons focus on traditional masculine activities, such as earning money, "at the expense of emotional ties, including those to their parents." "1

Generally, one adult child becomes the "primary caregiver" of the elderly parent-the child who actually furnishes the daily support and services needed to maintain the parent in the community. ${ }^{72}$ These support activities include the major and minor tasks associated with daily living, including emotional nurturing and caretaking activities such as feeding, bathing, dressing, and nursing. ${ }^{73}$ The literature clearly indicates that, in the absence of a spouse, the primary caregiver for the elderly parent is a daughter, daughter-in-law, or niece. ${ }^{14}$ As a result, when contemporary writers bemoan the pressures on the "sandwich generation" —adults pressured by simultaneous responsibilities to their own children and to their parents-they are identifying a gender issue. In reality, it is women who must balance work and family, meeting the competing demands of responsibilities to their careers, husbands, children, and parents.

The Family and Medical Leave Act of $1993^{76}$ fails adequately to address the many problems facing the "sandwich generation" of middle-aged women responsible for caretaking their own children as well as their elderly parents. ${ }^{77}$ Specifically, the Act permits unpaid worker leave to care for a seriously ill son, daughter, or parent. ${ }^{78}$ To date, the practical effect of the Act has been felt more in

70. Id. The term "filial responsibility" refers to an adult child taking some responsibility for the financial and emotional care of aging parents. Id. The term "role" is "a set of prescriptions and proscriptions for behavior-expectations about what behaviors are appropriate for a person holding a particular position within a particular social context. A gender role, then, is a set of expectations about what behaviors are appropriate for people of one gender." Id. at 246 (citing S.J. KELLSER \& W. MCKenNa, Gender: An EthnOMEThodological APPROACH 18 (1978)).

71. Id. at 245 .

72. Id. at 249.

73. Id.

74. Id. at 250 .

75. The apparently gender-neutral term "sandwich generation" may be inaccurate. See Dorothy Miller, The "Sandwich" Generation: Adult Children of the Aging, SocIAL WORK 419-23. The preferred term may be "women in the middle"-an alternative term used in sociological literature. Matthews, supra note 1, at 250.

76. See Family and Medical Leave (FMLA) Act, 29 U.S.C. $§ \S 2601,2612$ (1995) (providing worker leave following a birth of a child, or to care for a seriously ill child or parent). For a discussion of the complexities of the FMLA, see Shelly B. Kroll, An Employee's Perspective on the Family and Medical Leave Act, 38 B. B.J., Sept./Oct. 1994, at 4; Jay M. Rector, Family and Medical Leave Act of 1993, 64 J. KAN. B.A., May 1995, at 22, 39.

77. See, e.g., Donna R. Lenhoff \& Sylvia M. Becker, Family and Medical Leave Legislation in the States: Towards a Comprehensive Approach, 26 HARV. J. ON LEGIS. 403, 417 (1989). See generally Nancy R. Daspit, The Family and Medical Leave Act of 1993: A Great Idea But a "Rube Goldberg" Solution?, 43 EMORY L.J. 1351, 1352 (1994); Elizabeth A. Hall, Balancing Work and Family: A Legal Perspective, 32 Hous. LAw., Nov./Dec. 1994, at 18.

78. 29 U.S.C. $\S 2612(C)(1995)$. The fact that this leave is unpaid means that fewer than one third of employees can afford to take such leave. Judy Mann, Taking Family Leave to the Next Step, WASH. POST, May 30, 1997, at E03. See also Donna Lewhoff \& Claudia Withers, Implementation of the Family and Medical Leave Act: Toward the Family-Friendly Workplace, 3 J. GENDER \& LAW 39, 53 (1994). 
the area of maternity leave than in the caregiving of elderly parents. ${ }^{79}$ Since the Act provides only twelve weeks of leave, it cannot meet the long-term needs of elderly parents and their adult children.

International perspectives on family leave may offer helpful counterpoints to the American perspective. ${ }^{80}$ Admittedly, foreign legislation also has focused on maternity leave issues, including the desire to involve fathers in the caretaking of their infants. For example, "Sweden introduced parental leave to make it possible for more parents to combine family and working lives, with the aim not only of enabling more women to take on dual roles but also as a deliberate attempt to strengthen the family, and the man's role in it." ${ }^{\text {.81 }}$

The situation in contemporary Japan is particularly instructive. Japan has the highest proportion of households with three generations living together ${ }^{82}$ In fact, seven of ten elderly Japanese live with their adult children. ${ }^{83}$ The method by which the Japanese legal system encourages both public and private responsibilities for the elderly provides useful insights. Article 877 of the Japanese Civil Code provides that the care and support of an elderly person is the responsibility of that person's relatives ${ }^{84}$ Significantly, the Japanese government has recognized the problems of aging as a gender issue. ${ }^{85}$ Japanese proposals include creating a new pension system for women that would recognize a mother's absence from the workforce to rear children. ${ }^{86}$

These issues become critical in light of simple demographic reality. During the past fifty years, we have seen dramatic changes in the demographics of the elderly. ${ }^{87}$ Worldwide, in 1990 the percentage of the total population composed of persons sixty-five years old or older increased from $5.1 \%$ in 1950 to $6.2 \%{ }^{88}$

79. See, e.g., Martin H. Malin, Fathers and Parental Leave, 72 TEX. L. REV. 1047 (1994).

80. See generally Mikel A. Glavinovich, International Suggestions for Improving Parental Leave Legislation in the United States, 13 ARIZ. J. INT'L \& COMP. L. 147, 168-69 (1996); Carol Daugherty Rasnic, Balancing Respective Rights in the Employment Contract: Contrasting the U.S. "EmploymentAt-Will" Rule with the Worker Statutory Protections Against Dismissal in European Community Countries, 4 J. INT'L L. \& PRAC. 441, 455 (1995); Carol Daugherty Rasnic, The United States' 1993 Family and Medical Leave Act: How Does It Compare with Work Leave Laws in European Countries?, 10 CONN. J. INT'L. L. 105, 133 (1994); Carol Daugherty Rasnic, Who Holds the Employment Contract "Trump Card"? Comparing Labor Laws in Germany and the United States for the International Investor, 4 IND. INT'L \& COMP. L. REV. 33, 54-55 (1993).

81. See Glavinovich, supra note 80, at 172 (quoting Doreen Taylor-Wilkie, The Men Who Opt for Home, THE HERALD (Glasgow), Oct. 11, 1994, at 25).

82. Toshio Shinmura, Japan: Plan to Live Beyond Age 80, EPA Urges-Social Norms Will Change, White Paper Warns, JAPAN ECON. J., Nov. 21, 1994, at B2.

83. Suzanne Daniel, Growing Old in Japan: Lifestyle-50 Plus, SIDNEY MoRNING HeRALD, May 25,1994 , at C3.

84. Daisaku Maeda, Decline of Family Care and the Development of Public Services-a sociological analysis of the Japanese Experience, in AN AGNG WORLD: DLEMMAS AND CHALLENGES FOR LAW AND SOCIAL POLICY 297, 298 (John M. Eekelaar \& David Pearl eds., 1989).

85. Nihon Keizai Shimbun, Women Move into Research Field: Social Issues Neglected by Men Come to the Fore, JAPAN ECON. J., July 13, 1992, at B5.

86. Id. See also Yoshinori Kamo, A Note in Elderly Living Arrangements in Japan and the United States, in GROWING OLD IN AMERICA, supra note 9, at 377.

87. Linda G. MARTIN \& SAMUel H. PReston, Demography of AgING 2 (Linda G. Martin \& Samuel H. Preston eds., 1994).

88. RICHARD A. POSNER, AGING AND OLD AGE 35 (1995). 
Moreover, this figure is expected to increase to $8.7 \%$ by $2020 .^{89}$ These figures are even higher for the United States population: $8.1 \%$ in $1950,12.6 \%$ in 1990 , and $17.5 \%$ in $2020 .{ }^{90}$ Even more striking is the percentage of the population that is age eighty or older. In the United States, the percentages of population eighty years old or older are as follows: $1.1 \%$ in $1950 ; 2.8 \%$ in 1990 ; and an expected $3.9 \%$ in $2020 .^{91}$ These increases in the elderly population can be traced to rising real incomes, improved health care, ${ }^{92}$ and a decline in the birth rate.

\section{Economic Issues of Aging}

Traditionally, scholars have examined the economic issues of aging as rational, conscious decisions concerning consumption. ${ }^{93}$ Richard A. Posner argues:

[T]hat economics can do a better job of explaining the behavior and attitudes associated with aging, and of solving the policy problems that aging presents, than biology, psychology, sociology, philosophy, or any other single field of natural or social science. $^{94}$

Economic theory can be applied to aging and elder law issues. Essentially, this involves employing economic theory to examine non-market behavior. ${ }^{95}$ An economic theory readily applicable to elder law issues is "human capital," a term economists employ to describe the income-generating skills individuals acquire to generate financial returns. ${ }^{96}$ The formation of human capital develops in discrete phases: (1) the acquisition phase; (2) the paying returns phase; and (3) the capital depreciation phase. ${ }^{97}$ Investing in education is an example of human capital. For example, a student is willing to incur direct costs, such as tuition and books, and indirect costs, such as lost income during school attendance, to acquire skills that will yield greater income across a lifetime of earnings. ${ }^{98}$ In general, women have less human capital, ${ }^{99}$ just as they may have less physical capital. ${ }^{100}$

89. Id.

90. Id.

91. Id.

92. In 1979, there were an estimated 130,000 open-heart coronary bypass surgeries; in 1992, the number rose to 480,000 . In 1968 , there were 23 heart transplant surgeries in the United States; in 1993, there were about 2,300. Am. Heart Ass'N, Heart AND Stroke Facts, 1995 Statistical SUPPLEMENT 21 (1995).

93. See, e.g., Michael D. Hurd, Research on the Elderly: Economic Status, Retirement, and Consumption and Saving, 28 J. ECON. LITERATURE 565, 569 (1990). See generally STUDIES IN THE ECONOMics OF AGING (David A. Wise ed., 1994).

94. See POSNER, supra note 88, at 2. For an example of the application of economic theory to the family, see Gary Becker, The Economic Way of Looking at Behavior, 101 J. PoL. Econ. 385, 395401 (1993).

95. For other examples of applying economic theory to non-market behavior, see generally Richard A. Posnér, SeX AND Reason (1992); Becker, supra note 94.

96. POSNER, supra note 88 , at 61-65.

97. Id. at $51-53$.

98. Id. at 51-52.

99. See, e.g., Schwartz, supra note 49 , at 65 .

100. See, e.g., LenORE J. WeitzMAN, THE Divorce Revolution 337-56 (1985). 
Closely related to the human capital issue is the problem of "multiple selves."101 Simply put, philosophers and economists recognize that individuals may be unable to make consistent decisions over a long period of time. ${ }^{102}$ Typically, individuals favor the present over the future in making decisions. Moreover, in considering issues of personal choice and identity, individuals question whether one remains the "same" person over a lifetime, or whether the individual is somehow different over time--in actuality not "one self," but rather "multiple selves."

The role of gender in the related issues of human capital and multiple selves deserves special consideration. For example, a woman's "choice"104 to balance work and family issues by focusing her attention on childrearing to the detriment of career advancement may come from an inability to bring the future clearly into current decisionmaking. ${ }^{105}$ Correction of inconsistent preferences over time is not a simple matter of providing individuals with accurate information; they will simply ignore and distort that information. For example, many women today choose to "mommy track," 106 or "sequence," 107 in order to fulfill their responsibilities as wives, mothers, and daughters. The immediate and long-term consequences of these choices contribute to the "feminization" of poverty. ${ }^{108}$ Basically, the longterm economic effects of placing family responsibilities first ${ }^{109}$ lead to the impoverishment of single, ${ }^{110}$ divorced, ${ }^{111}$ and elderly women. ${ }^{112}$

The current pension system both reflects and exacerbates the gender income gap. ${ }^{113}$ At retirement, women receive less than one-third of the employer-provided

101. See POSNER, supra note 88 , at 84-85.

102. See generally Robert Strotz, Myopia and Inconsistency in Dynamic Utility Maximization, 23 REV. ECON. STUD. 165 (1955-56) (explaining that individuals may have a systematic problem in making lifetime consistent decisions).

103. See POSNER, supra note 88 , at 84-85.

104. The "choice" to focus primary attention on familial caretaking responsibilities may not be so much a choice as an accommodation to social and economic pressures. Making a choice to subordinate her future economic needs may be analyzed according to Antonio Gramsci's concept of cultural hegemony: the dominant culture shapes a "hegemony" of norms and values which limits discourse and, ultimately, choice. See ANTONo Gramsci, SElECTIONS From tHE PRISON NoteBOOKS 37-54 (Q. Hoare \& G. Smith eds. \& trans., 1971).

105. See Thomas S. Ulen, Rational Choice and the Economic Analysis of Law, 19 L. \& Soc. INQ. 487 (1994).

106. See generally Schwartz, supra note 49, at 70-72.

107. See generally Sheila Nielsen, The Balancing Act: Practical Suggestions for Part-Time Attorneys, 35 N.Y.L. SCH. L. REV. 369, 380-83 (1990).

108. See WeITZMAN, supra note 100 , at 337-40.

109. Heidi Hartmann, Achieving Economic Equity for Women, in WINNING AMERICA: IDEAS AND LEADERSHIP FOR THE 1990S, at 99 (M. Raskin \& C. Hartman eds., 1988) (suggesting that the traditional workplace must be completely transformed such as implementing a six-hour work day for all workers). See also Martha L. Fineman, Implementing Equality: Ideology, Contradiction and Social Change: A Study of Rhetoric and Results in the Regulation of the Consequences of Divorce, 1983 Wis. L. REV. 789, 791 (suggesting that reform of the economics of divorce must have the primary focus of equality).

110. See, e.g., Gary Burtless, Comments on Income for the Single Parent: Child Support, Work, and Welfare, in GENDER IN THE WORKPLACE 263 (Clair Brown \& Joseph Pechman eds., 1987).

111. See WEITZMAN, supra note 100, at 337-56.

112. See supra notes 65-66.

113. See supra notes 65-67. 
retirement benefits received by men. ${ }^{114}$ Since pensions generally are based on a formula combining the number of years worked and the actual earned salary, the gender gap actually widens during retirement. ${ }^{115}$ Senator Carol Moseley-Braun notes that "a woman with a forty-year career who takes seven years out of the workplace may get half of the pension benefits she might have enjoyed with continuous employment."116

Moreover, women who perform the traditional role of wife, without ever entering the paid workplace, risk impoverishment from divorce or widowhood. Almost eighty percent of women who are poor as widows were not poor before their husbands' deaths. ${ }^{117}$ Ultimately, the hardships created by this widening gender income gap results in "an increased demand for transfer payments and public support."118 To avoid these societal costs, both the workplace and the family must be transformed.

\section{Transforming Elder Law Through the ETHic of CARE}

Displacing contemporary elder law principles of autonomy and independence with the feminist ethic of relational care can help alleviate these gender-based inequities. As previously discussed, Carol Gilligan's landmark book, In a Different Voice, embodies two complementary themes. Popular literature has embraced "different voice" theory, ${ }^{119}$ while basically ignoring the equally significant second theme. Gilligan argues that traditional gender stereotypes limit human potential for leading a balanced life. ${ }^{20}$ Ultimately the feminist ethic of care rejects the distortion and impoverishment of both men's and women's lives, produced by these traditional gender roles. It seeks to replace these stereotypes with gender-neutral paradigms which require transformation of both home and workplace. ${ }^{121}$ More specifically, the family and the workplace must be transformed to permit both men and women to participate fully in both arenas without risking the loss of income, status, or security. ${ }^{122}$

This jurisprudence establishes gender-neutral relational care as the cornerstone of family life. The advantage of such gender-neutral policies is to move beyond mere formal equality in an attempt to achieve substantive equality between men and women. ${ }^{123}$ Restructuring workplace expectations must be accomplished in ways

114. Carol Moseley-Braun, Women's Retirement Security, 4 ELDER L.J. 493, 494-95 (1996) (citing Kerry Hannon, $A$ Woman's Special Dilemma, U.S. NEWS \& WORLD REP., June 13, 1994, at 93).

115. Id.

116. Id.

117. Id.

118. Id.

119. See supra discussion at part II.

120. GILligan, supra note 23, at 62-63. See also Carrie Menkel-Meadow, Portia in a Different Voice: Speculations on a Women's Lawyering Process, 1 BERKELEY WOMEN's L.J. 39, 55-60 (1985).

121. See, e.g., Joan C. Williams, Deconstructing Gender, in FEMINIST JURISPRUDENCE 531 (Patricia Smith ed., 1993).

122. Id. at 542-51.

123. See, e.g., Wendy W. Williams, Notes from a First Generation, 1989 U. CHI. LEGAL F. 99, 108-110. 
that do not perpetuate work/family conflicts as merely a woman's problem. ${ }^{124}$ Essentially, such workplace restructuring must "reshape male-centered attitudes" so that changes intended to help women do not ultimately devalue them. ${ }^{125}$

For example, attending to the responsibilities of childrearing and care of elderly parents should not exact drastic career costs. These family responsibilities should not be viewed as "interruptions" to career advancement which can never be overcome. ${ }^{126}$

Moreover, workers who balance work and family may bring to the workplace significant qualities, developed in family care of a child or elderly parent, which make them more productive workers. These qualities, often identified as "feminine" attributes, include empathy, flexibility and patience. ${ }^{127}$ Relational caring has been demonstrated to add to a personal sense of well-being and to conscious control over life responsibilities. ${ }^{128}$ If true "family values" are to be promoted by American jurisprudence, men and women must be equal participants in both the home and the workforce. The feminist ethic of care provides a framework for achieving this necessary goal.

124. Nancy E. Dowd, Work and Family: The Gender Paradox and the Limitations of Discrimination Analysis in Restructuring the Workplace, 24 HARV. C.R.-C.L. L. REV. 79 (1989).

125. Kathryn Abrams, Gender Discrimination and the Transformation of Workplace Norms, 42 VAND. L. REV. 1183, 1220-48 (1989).

126. See, e.g., Mary Jo White, Glass Ceilings and Open Doors: A Response, 65 FordHAM L. REV. 619, 620 (1996).

127. Tammy Audeh, Graduation: Words from the Famous to Those Who May Be. N.Y.TIMES, May 29, 1995 at 9. Gloria Steinman, addressing Smith College graduates, said:

[U]ntil men raise children as much as women do-and are raised to raise children, whether or not they become fathers - they will have a far harder time developing in themselves these human qualities that are wrongly called "feminine," but are really these necessary to raise children: empathy, flexibility, patience, compassion, and the ability to let go.

Id.

128. BetTy Friedan, THE Fountain of AGE 536 (1993) (discussing the work of Alexis J. Walther and Clara C. Pratt). 